\title{
Climate-Smart Rice
}

\begin{abstract}
Rice is grown in a huge range of locations across over 160 million hectares of the planet, from the cool temperate regions of Northeast Asia, through low-lying river deltas in the tropics, to lofty Himalayan mountain slopes at altitudes of over 2 kilometres. To produce each kilogram bag of Basmati rice, the climate-warming equivalent of over a kilogram of carbon dioxide (mainly in the form of methane) is also emitted. Along with some nitrous oxide from the use of nitrogen fertilisers on the fields, the life-cycle emissions can top 1.5 kilograms per kilogram. In Britain rice wastage amounts to over 40,000 tonnes each year and so the equivalent of around 60,000 tonnes of greenhouse gas emissions. Drought, flood, heat and disease are all major risks that may be exacerbated by climate change. Loss of irrigation water supplies due to melting of glaciers in the Himalayas is a major concern for rice growers in South Asia. Improved water management can give greater resilience to climate change and radically reduce methane emissions at the same time.
\end{abstract}

Keywords Basmati $\bullet$ Punjab $\bullet$ Pakistan $\bullet$ India $\bullet$ Methane $\bullet$ Methanogens $\bullet$ Alternate wetting and drying $\bullet$ Drainage $\bullet$ Rice straw $\bullet$ Puddling • Irrigation • Himalayas • Glacial melt

Along with last night's chicken curry is a portion of leftover Basmati rice. Each year we consume over 500 million tonnes of this unassuming grain. It is the main source of nourishment for over a billion people and has been

(C) The Author(s) 2019

D. Reay, Climate-Smart Food, https://doi.org/10.1007/978-3-030-18206-9_10 
at the heart of global food security for centuries-rice has been found at archaeological sites dating as far back as 8,000 BC. Today there are two main domesticated types: Oryza sativa (known as Asian rice) and Oryza glaberima (or African rice) [1]. Within these groups, however, there are more than 4,000 varieties-even Basmati has its own cadre of forms, from Super Basmati (long grained and aromatic) to Shaheen Basmati (a salttolerant variety grown in areas where brine has contaminated ground waters) [2].

Rice is grown in a huge range of locations across over 160 million hectares of the planet, from the cool temperate regions of Northeast Asia, through low-lying river deltas in the tropics, to lofty Himalayan mountain slopes at altitudes of over 2 kilometres. What all these growing areas have in common is a good supply of water [3].

The goliaths of rice production, and consumption, are China and India. Together they make up more than half of the global harvest, amounting to over 350 million tonnes of rice each year [4] (Fig. 10.1). India and

Rice production, 2014

Annual paddy rice production, measured in tonnes per year.

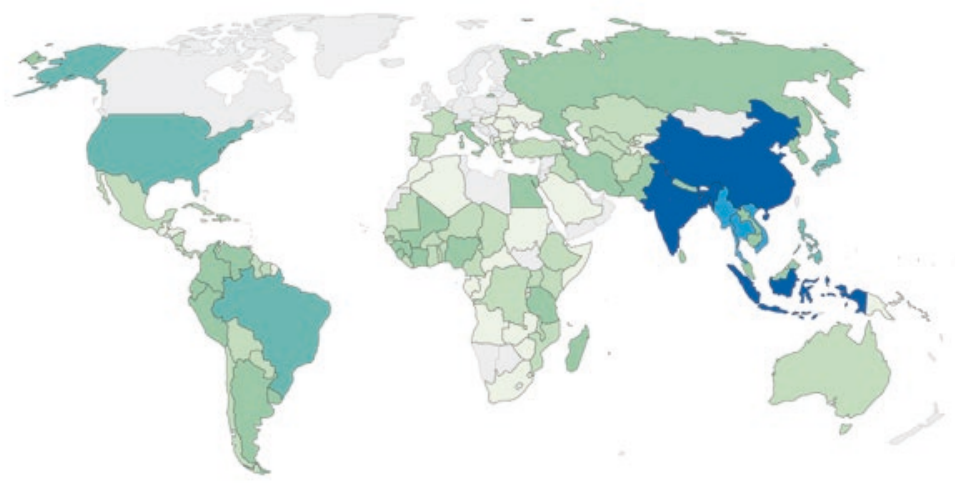

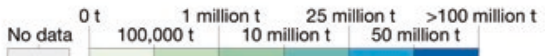

Fig. 10.1 Global rice production in 2014 by country of origin (Source: Hannah Ritchie, Our World in Data) [6]. Available at: https://ourworldindata.org/ grapher/rice-production 
Thailand lead the global pack in terms of exports to big foreign markets like the European Union and the US. For our own re-warmed Basmati, the heartlands of production are found in northwestern India and eastern Pakistan, especially the humid, sub-tropical expanses of Punjab [5].

Basmati rice grown in the fields of Indian and Pakistani Punjab is well known for long, slender grains and its popcorn-like fragrance-the name Basmati translates from Hindi as queen of fragrance [2]. It owes its beguiling aroma to high levels of aromatic compounds, and Basmati commands a premium market price as a result [7]. The plants need prolonged sunshine, high humidity and plenty of water, so thrive in Punjab's warm and wet sub-tropical climate, where high temperatures early in the year give way to a warm and humid rainy season from June to September.

Most rice is first grown as seedlings in nursery plots for about a month and then transplanted to the waiting fields. The flooded paddy soils are prepared by puddling-dragging a harrow up and down through the water-covered soils to stir up clay particles that then block pores in the soil. Once the seedlings are planted, the puddling means more water is retained, weeds are killed off and the young rice plants can begin growing with their roots fully immersed.

In the irrigated systems common to Punjab, the rice paddies are kept submerged for 2 to 4 weeks after planting and then irrigated again as the water drains into the soil. Nitrogen and phosphorous fertilisers are added (ideally at times when the fields are not flooded) to boost plant growth, along with fungicides and insecticides. If all goes well then the grain-heavy rice plants should be ready for harvest within about 4 months. Fields are allowed to drain prior to harvest in October and November so as to make collection easier and have the soil ready for the planting of a follow-on crop. The quality of rice is very sensitive to temperature-cooler, slower growth tends to mean better cooking and taste, while hotter temperatures can mean the rice produced becomes sticky during cooking and loses its much sought-after flavour [8].

After harvest the rice is threshed and cleaned to separate good grain from straw and immature seeds, before being bagged up for transport and processing. If the moisture content is high (above about 15 per cent), the rice is also dried to reduce spoilage risks. For the perfect white rice we know and love in Britain, the grains are milled. The rice husks, any soil particles and the dark outer layers of the grains - the bran-are removed (for brown rice, this bran layer is retained). Individual grains of white rice 
are then polished and graded by size to filter out any that are broken or misshapen [9]. Perfect whole grains of Basmati rice are the premium result of all this processing, but little is wasted - the husks are often used for fuel, the bran is used for animal feed and to make bran oil, and the broken rice fragments (called brewers' rice) are used for making beer, rice flour or noodles. If the harvest is destined for international markets like the UK, it travels by truck to the coast and is then shipped from large ports like Karachi.

Harvesting and processing, transport and cooking, each contribute to the total carbon footprint of the rice we consume. These emissions come largely from fossil fuel use and add up to around 80 grams of carbon dioxide for each kilogram of rice produced [10]. As with most foods, however, it's the growing of the rice in the first place that dominates its life-cycle emissions. Waterlogged fields like those in which Basmati is often grown are the perfect home for that climate-changing group of microbes that is the 'methanogens'. Just as these microbial methane-producers enjoy the warm, low-oxygen and carbon-rich environs of dairy cow rumens (Chap. 5 ), so they can thrive in the muddy sediments of rice paddies. Paddy soils overlain for long periods with standing water provide exactly the conditions they need to proliferate-the methane gas then either diffuses up through the overlying water and sediment, is released via bubbles, or finds its way up the stems of the plants and out into the air. With huge areas of land under cultivation, and soils that are often methane-producing hot spots, rice is a major source of human-induced methane emissions worldwide [11].

To produce each kilogram bag of Basmati rice, the climate-warming equivalent of over a kilogram of carbon dioxide (mainly in the form of methane) is also emitted. Along with some nitrous oxide from the use of nitrogen fertilisers on the fields, the life-cycle emissions can top 1.5 kilograms per kilogram of rice [10]. This footprint means that any wastage has a significant climate cost too. Spoilage due to the harvest being too moist or badly stored can be a problem, as can water damage and poor ventilation during the long journey by sea to foreign markets [12]. For consumers, the fact that the rice we buy is usually well dried and packaged means relatively little goes past its use-by date. Much more common is wastage from preparing and serving too much.

In Britain such avoidable waste amounts to over 40,000 tonnes of rice each year [13] and so the equivalent of around 60,000 tonnes of greenhouse gas emissions. Cooking only what is required, serving only 
what is wanted and using any leftover cooked rice for other meals are again the leading responses. In truth, judging just the right amount of rice can be tricky-its huge expansion when cooked often means an amount that looked about right in dried form turns into a daunting heap at the dinner table. Measuring cups can help, and if the inevitable overload still happens, then at least rice is great for combining with other meals. Once cooked though, care must be taken that leftovers are well refrigerated and consumed fairly quickly - bacterial growth in cooked rice can be rapid, and so food poisoning becomes a risk if it is left uneaten for too long [14].

With rice being grown in so many different areas around the world, the threats its farmers face from severe weather events, pests and diseases are manifold. The Basmati growers of the Punjab are all too aware of most of them. Since the 1960s maximum spring temperatures have increased markedly. Alongside this has come higher rainfall, sometimes with disastrous effects [15].

Rice plants like it wet, but extreme rainfall events can destroy the retaining banks around paddies, erode their soils and, if submerged too long, kill the plants too [16]. Across Asia, millions of tonnes of rice are lost each year due to flooding. In July and August of 2010 heavy and prolonged rainfall caused devastation in Pakistan, leaving one-fifth of the land area submerged [17]. These floods claimed the lives of over 1,600 people and forced two million from their homes. In the Punjab over half a million hectares of cropland were inundated. Wheat, cotton and sugar farming were all badly hit, and an estimated 200 thousand tonnes of rice were lost [18]. The wet season of 2014 again saw record-breaking rainfall across the Punjab, with Lahore enduring 300 millimetres of rain (around half of the annual average) in just 24 hours.

As the quality of Basmati rice is very dependent on temperature-the plants need a relatively cool period of growth to fill their 'ears' with the largest, best-tasting grains-heat waves can also spell disaster. The hottest period in the Punjab tends to be from May to June, when daytime temperatures above 40 degrees Celsius are the norm. Pakistan is no stranger to heat waves, experiencing an average of 7 every year [19] (in 2010 the southern city of Mohenjo Daro re-wrote the Asian record books with a temperature of $\mathbf{5 3 . 5}$ degrees Celsius). For Pakistani Punjab such extreme temperatures are rare, but the thermometer often pushes past 
45 degrees Celsius in its capital, Lahore, and in May 2018, rice-growing epicentres on both sides of the Pakistan-India border were hit [20]. Climate change is set to enhance both the frequency and severity of such heat waves. Under a high-emissions scenario, the chance of heat waves in Punjab may increase by one-third by as early as 2030 . By the end of the century, it could more than double [21].

The risks of climate change to Punjabi rice growers are already apparent. Warming is approaching critical levels in the Basmati-growing heartlands due to it coinciding with times when the rice plants are at their most susceptible [22]. By the second half of the century, annual average temperatures in the region could increase by more than 3 degrees Celsius [23]. As each degree of night-time warming can cut rice yields by 10 per cent [24], such a rise could see rice harvests fall by more than a quarter.

For rainfall the outlook appears brighter, average amounts falling each year are not expected to change much in the coming decades. Instead, it is more variability in where and when rain occurs that risks causing damage through torrential downpours and flash flooding. Where this same variability means more drought, the fact that nine out of ten rice fields in the Punjab have irrigation should help give resilience. For many thousands of rice farmers in South Asia, however, it's the impact of warming on the distant frozen source of this vital irrigation water that is really focussing minds.

Both the Indus and Ganges rivers derive much of their dry season flow from Himalayan glaciers. The Indus - a river whose waters irrigate the crops on which more than half of the Pakistani population depends-will see lower flows as the glaciers high up in the Himalayas succumb to rising temperatures. By the middle of the century melt waters from these lofty peaks may have diminished by a third. The timing of the melt could make things even worse. As temperatures increase, so the glacial waters are released ever earlier in the year. For South Asia this means that river tributaries relied on for irrigation water may flow much faster during the wet season (when irrigation is less crucial) but then trickle to a halt in the dry season, just when they are needed most. Lower river flows also mean ground waters and aquifers are recharged more slowly-in north western India and eastern Pakistan, water tables are already falling and wells drying up [22].

Ironically, as water shortages become ever more likely for the rice growers of Asia, one saving grace could come in the form of more carbon dioxide. The same increases in carbon dioxide concentrations that are 
driving up global temperatures also make for faster plant growth and so, potentially, bigger rice yields. A doubling of concentrations in the atmosphere could boost harvests by a quarter-the extra carbon dioxide also means water demands of plants are reduced (helping buffer drought impacts). The climate change impacts that come with a 2 -degrees-Celsius temperature rise, however, would cancel out much, if not all, of this positive carbon dioxide fertilisation effect [25].

Lurking as a diminutive threat that could take advantage of all these changes are the myriad pests and diseases that beset rice plants. Basmati is especially susceptible to stem borers. These pernicious insects feed on the still-forming tillers of rice (the stems that should go on to carry seed) and can devastate harvests- the striped stem borer common to Asia is able to wipe out whole crops [26], and in India stem borers have been putting holes in yields for decades [27]. Leaf hoppers also cause a lot of damage in rice paddies. Attack by high populations of these tiny insects causes the rice leaves first to turn yellow-orange, and then to die. As they feed, leaf hoppers may transmit incurable diseases like the beautifully descriptive Rice Ragged Stunt [28]. Higher temperatures appear to be a boon for rice pests like the Brown Leaf Hopper, as they reduce winter mortality rates and, in the hottest months, may kill off natural predators and so allow pest populations to soar [29]. A warmer winter season is also expected to benefit leaf blast, a fungal disease that attacks rice leaves causing a scattering of grey-green lesions that gradually expand across the entire leaf surface until it is dead [30]. Where higher carbon dioxide concentrations boost plant growth, diseases like leaf blast can take even greater advantage, as the lusher rice leaves appear to become more susceptible to invasion and destruction [31]. Rice farmers around the world already lose over a third of their crop to pests and diseases [32], so a climate boost to all the borers, hoppers and stunts is the last thing they need.

For the rice growers of Pakistan, including those that provided my own lunchtime Basmati, the many interactions of a changing climate by the middle of the century are predicted to increase the area on which rice is grown by around 2 per cent, but to simultaneously cut yields by almost 6 per cent [17]. At the heart of climate-smart responses to the increasing threats posed by flood, drought and faltering Himalayan melt water supplies is water management. Here, a system of alternate wetting and 
drying is already used to boost resilience. About two weeks after transplanting of the seedlings, the fields are allowed to dry out. Farmers then closely monitor how saturated the paddy soils are using a simple pipe (called a pani) that has holes drilled along its bottom half. The pani-pipe is pushed vertically down and the soil inside is scooped out so that the saturation of the field can be easily checked by looking down the pipe to see what level the water table is sitting at [33]. When it drops too far the field is flooded again. This simple monitoring means farmers can forego constant flooding and instead inundate the rice only during the critical growth stages, such as flowering. By better matching the needs of the plants, and so saving water, they can reduce vulnerability to droughts and to faltering irrigation sources [17]. Along with greater climate change resilience comes a major bonus in the form of reduced methane. Periods of alternating wet and dry conditions mean that more oxygen can penetrate the soils and the multitudes of methanogens they contain are knocked back. Over the course of the rice-growing season, this practice can halve methane emissions [34], and so slice as much as one-third off the total lifecycle carbon footprint of the rice produced.

Yields can benefit from such improved water management too. Growers from right across Asia report a boost to harvests and lower losses from lodging-where plant stems are bent over by wind or rain [35]. Lodging makes the rice harder to harvest and more prone to pest and disease attacks (rice plants have short roots and are especially vulnerable). Periods of flood-free soil mean the plants establish deeper roots, are better at resisting the pushes and pulls of strong winds and torrential downpours, and are more able to cope with any intense droughts that occur [36].

As a climate-smart approach, improved water management in rice agriculture has become somewhat of a poster boy. There are some caveats, such as slight increases in emissions of nitrous oxide (allowing more oxygen into the soil promotes its production) and the potential for more weed problems (constant flooding helps control weeds), but time and again, the approach has delivered on the magic triumvirate of bigger harvests, greater climate resilience and lower emissions.

Still more climate benefits can be gained by careful management of rice straw after harvest and the timing of manure, compost and fertiliser applications. For rice straw, dropping piles of freshly cut stalks into the stagnant water of the paddies provides a feast for the methanogens. Composting it at the side of the field instead, and then applying it back to dry soils during the off-season, means much less methane is produced and 
soil carbon is enhanced. Some farms even turn the methanogens into an ally, collecting together the rice straw and any available manure and allowing this carbon-rich mix to decompose in sealed digesters where the methane produced is then collected and used as fuel [37].

Like water, closely matching the use of fertilisers with the needs of the plants as they grow can bring big dividends. Too little nitrogen, for instance, and the plants will be stunted, turn yellow and produce little grain. Too much, and the excess nitrogen will pollute drainage streams and increase emissions of ammonia and nitrous oxide to the atmosphere. Leaf colour charts-simple sheets printed with four coloured strips in different shades of green-are commonly used to allow farmers to gauge whether their crop is looking too yellow and so needs a fertiliser top-up [38]. As every field and crop is different, site-specific nutrient management is much more effective than a one-size-fits-all approach. Alongside leaf colour charts, this can involve the calculation of the optimum water and fertiliser inputs, and their timings, based on the climate, soil type and management at each location. Trials by farmers in India have shown boosts in harvests of almost a tonne of rice and for each hectare where this approach is used [39].

Arguably the most powerful tool at our disposal to resist the climatepowered march of drought and flood, of pests and diseases, are the rice plants themselves. Rice has been the focus of intensive research and breeding programmes for decades, yielding famous varieties like 'Golden Rice' - a genetically modified plant intended to help address vitamin A deficiency in children and pregnant women [40]. Others have been developed to have shorter stems (to reduce lodging) and to be more drought, flood or even salt tolerant - rising sea levels are pushing saltwater further and further inland [16].

In areas where a particular pest or disease is rife, planting a rice variety that has good resistance to it is often the most cost-effective first line of defence. Good follow-up practices include regular cleaning of equipment, stores and fields to avoid disease spread, avoiding over-application of fertilisers (this makes the plants more susceptible to attack) and encouraging natural pest predators by providing habitats and limiting pesticide use [32]. Part of a climate-smart response is planning (and planting) ahead for new pest and disease risks as temperatures rise and rainfall patterns change. It also requires understanding of the ways in which severe weather events could undermine traditional controls-for example, more intense rainfall washing pesticides into drainage waters. 
Of course, having a wealth of rice varieties to better fit with local conditions and future climates is of little use if they are not accessible to farmers or the climate change impact projections are too uncertain. Organisations like the International Rice Research Institute are actively translating the latest knowledge on plant breeding and rice farm management into practice around the world. At the local level, well-funded extension services are also needed to provide a gateway to finance and technology and allow farmers to learn about solutions like alternate wetting and drying, sitespecific nutrient management and the rest.

Sharing of best practice and expert advice through farmer field schools has already led to some rice growers in Afghanistan doubling their yields while at the same time slashing their water use, fertiliser inputs and incidences of pest and disease attack [41]. In Pakistani Punjab, an increasing number of farmers are making use of laser levelling technology to ensure rice fields are flat, water leakages are reduced, and patches that will become too wet or dry are avoided. This relatively simple technology (a laser beam is fired from a box on the side of the field and hits a receiver on the farmer's plough to guide its depth) is used during preparation of a rice paddy, but so far, its wider uptake has been hobbled by a lack of funding [17].

The enormous scale of rice production and consumption means that achieving a climate-smart future for this mealtime staple has implications for food security worldwide. The Basmati growers of Punjab are in the vanguard of farmers trying to boost yields and the resilience of their crops while at the same time cutting emissions. The devastating floods of 2010 left some 90 million people in Pakistan without a secure food supply [8]; climate-smart approaches, including those for rice, could help avoid even bigger threats to food security in the coming decades.

\section{REFERENCES}

1. Sweeney, M. \& McCouch, S. The complex history of the domestication of rice. Ann. Bot. 100, 951-957 (2007).

2. Ashfaq, M. Basmati rice a class apart (A review). Rice Res.: Open Access (2014).

3. Bouman, B. How much water does rice use. Management 69, 115-133 (2009).

4. EC. EU Rice Economic Fact Sheet. European Commission. https://ec.europa. $\mathrm{eu} /$ agriculture/sites/agriculture/files/cereals/trade/rice/economic-factsheet_en.pdf (2015).

5. APEDA. Basmati Survey Report. APEDA, New Delhi. http://apeda.gov.in/ apedawebsite/six_head_product/BSK-2017/Basmati_Report-1.pdf (2017). 
6. Ritchie, H. Global rice production, 2014. Ourworldindata.org. https://ourworldindata.org/grapher/rice-production (2018).

7. Gaur, A. et al. Understanding the fragrance in rice. Rice Res.: Open Access (2016).

8. AGRIPB. Cultivation of Basmati Rice. http://agripb.gov.in/pub/pdf/ cultivation_of_basmati_rice.pdf (2018).

9. IRRI. Rice Knowledge Bank-Milling. http://www.knowledgebank.irri.org/ step-by-step-production/postharvest/milling (2018).

10. Pathak, H., Jain, N., Bhatia, A., Patel, J. \& Aggarwal, P. K. Carbon footprints of Indian food items. Agri. Ecosyst. Environ. 139, 66-73 (2010).

11. Reay, D. S., Smith, P., Christensen, T. R., James, R. H. \& Clark, H. Methane and global environmental change. Annu. Rev. Environ. Resour. 43, 165-192 (2018).

12. Safety4Sea. Transportation of Rice Cargo. https://safety4sea.com/transportation-of-rice-cargo/ (2013).

13. WRAP. Household food and drink waste in the United Kingdom 2012. Waste and Resource Action Programme. http://www.wrap.org.uk/sites/files/wrap/ hhfdw-2012-main.pdf.pdf (2013).

14. Kelly, R. 22 recipe ideas for leftover rice. The Guardian. https://www.theguardian.com/lifeandstyle/2014/jun/03/22-recipe-ideas-for-leftover-rice (2014).

15. Khattak, M. S. \& Ali, S. Assessment of temperature and rainfall trends in Punjab province of Pakistan for the period 1961-2014. J. Himal. Earth Sci. 48, 42-61 (2015).

16. IRRI. Climate Change-Ready Rice. http://www.knowledgebank.irri.org/ step-by-step-production/pre-planting/rice-varieties/item/climate-changeready-rice (2018).

17. CIAT. Climate-smart agriculture in Pakistan. CSA Country Profiles for Asia Series. International Center for Tropical Agriculture (CIAT); The World Bank. Washington, DC. 28 p. http://sdwebx.worldbank.org/climateportal/doc/ agricultureProfiles/CSA-in-Pakistan.pdf (2017).

18. Anthony, A. \& Georgy, M. Pakistan floods destroy crops and could cost billions. Reuters. https://www.reuters.com/article/us-pakistan-floodsagriculture/pakistan-floods-destroy-crops-and-could-cost-billions-idUSTRE67B0EW20100812 (2010).

19. Shaikh, S. Pakistan faces increasing heat waves. Scidev.net. https://www.scidev.net/asia-pacific/climate-change/news/pakistan-faces-increasing-heatwaves.html (2018).

20. Timesofindia.com. Heat wave sweeps across Punjab, Haryana. https://timesofindia.indiatimes.com/india/heat-wave-sweeps-across-punjab-haryana/articleshow/64261124.cms (2018). 
21. Nasim, W. et al. Future risk assessment by estimating historical heat wave trends with projected heat accumulation using SimCLIM climate model in Pakistan. Atmos. Res. 205, 118-133 (2018).

22. Wassmann, R. et al. Regional vulnerability of climate change impacts on Asian rice production and scope for adaptation. Adv. Agron. 102, 91-133 (2009).

23. Carbonbrief. Mapped: How every part of the world has warmed-and could continue to warm. Carbonbrief.org. https://www.carbonbrief.org/mappedhow-every-part-of-the-world-has-warmed-and-could-continue-to-warm (2018).

24. Peng, S. et al. Rice yields decline with higher night temperature from global warming. Proc. Natl. Acad. Sci. 101, 9971-9975 (2004).

25. Mahajan, G., Singh, S. \& Chauhan, B. S. Impact of climate change on weeds in the rice-wheat cropping system. Curr. Sci. 102, 1254-1255 (2012).

26. IRRI. Rice Knowledge Bank-Stem Borer. http://www.knowledgebank.irri. org/training/fact-sheets/pest-management/insects/item/stem-borer (2018).

27. Muralidharan, K. \& Pasalu, I. Assessments of crop losses in rice ecosystems due to stem borer damage (Lepidoptera: Pyralidae). Crop Prot. 25, 409-417 (2006).

28. IRRI. Rice Knowledge Bank-Leafhopper http://www.knowledgebank.irri. org/training/fact-sheets/pest-management/insects/item/planthopper (2018).

29. Krishnaiah, K. \& Varma, N. Changing insect pest scenario in the rice ecosystem-A national perspective. Directorate of Rice Research Rajendranagar, Hyderabad 2012, 2-8 (2012).

30. IRRI. Rice Knowledge Bank-Blast (Leaf and Collar). http://www.knowledgebank.irri.org/training/fact-sheets/pest-management/diseases/item/ blast-leaf-collar (2018).

31. Kobayashi, T. et al. Effects of elevated atmospheric $\mathrm{CO}_{2}$ concentration on the infection of rice blast and sheath blight. Phytopathology 96, 425-431 (2006).

32. IRRI. Rice Knowledge Bank-How to Manage Pests and Diseases. http://www. knowledgebank.irri.org/step-by-step-production/growth/pests-and-diseases (2018).

33. Prithwiraj, D. Smart water management in rice by IRRI's cost effective panipipe method for sustainable and climate smart rice development. Int. J. Agri. Sci. 9, 4154-4155. https://bioinfopublication.org/files/articles/9_17_7_ IJAS.pdf (2017).

34. Richards, M. \& Sander, B. O. Alternate Wetting and Drying in Irrigated Rice. CGIAR Climate Change, Agriculture \& Food Security-Practice Brief Climate-Smart Agriculture. https://cgspace.cgiar.org/bitstream/handle/ $10568 / 35402 /$ info-note_CCAFS_AWD_final_A4.pdf? sequence= 9\&isAllowed=y (2014). 
35. Zhang, H., Xue, Y., Wang, Z., Yang, J. \& Zhang, J. An alternate wetting and moderate soil drying regime improves root and shoot growth in rice. Crop Sci. 49, 2246-2260 (2009).

36. Terashima, K., Taniguchi, T., Ogiwara, H. \& Umemoto, T. Effect of field drainage on root lodging tolerance in direct-sown rice in flooded paddy field. Plant Prod. Sci. 6, 255-261 (2003).

37. IRRI. Rice Knowledge Bank-Off-field Rice Straw Management. http://www. knowledgebank.irri.org/step-by-step-production/postharvest/rice-by-products/rice-straw/off-field-rice-straw-management (2018).

38. IRRI. Rice Knowledge Bank-Leaf Color Chart. http://www.knowledgebank. irri.org/step-by-step-production/growth/soil-fertility/leaf-color-chart (2018).

39. Buresh, R. J. Workshop on Balanced Fertilization for Optimizing Plant Nutrition' Sponsored by the Arab Fertilizer Association (AFA), the International Potash Institute (IPI) and the World Phosphate Institute (IMPHOS).

40. IRRI. Golden Rice. https://irri.org/golden-rice (2018).

41. Sapkota, T. B. et al. Reducing global warming potential through sustainable intensification of Basmati rice-wheat systems in India. Sustainability 9, 1044 (2017).

Open Access This chapter is licensed under the terms of the Creative Commons Attribution 4.0 International License (http://creativecommons.org/licenses/ by $/ 4.0 /$ ), which permits use, sharing, adaptation, distribution and reproduction in any medium or format, as long as you give appropriate credit to the original author(s) and the source, provide a link to the Creative Commons licence and indicate if changes were made.

The images or other third party material in this chapter are included in the chapter's Creative Commons licence, unless indicated otherwise in a credit line to the material. If material is not included in the chapter's Creative Commons licence and your intended use is not permitted by statutory regulation or exceeds the permitted use, you will need to obtain permission directly from the copyright holder.

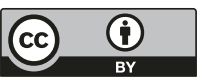

